\title{
Metal-complexing agents released into the marine environment by the deposit feeder Hydrobia ulvae (Gastropoda: Prosobranchia): characterization and regulation processes
}

\author{
Th. Tournié ${ }^{1} \&$ H. El Mednaoui ${ }^{2}$ \\ ${ }^{1}$ Station Biologique, CNRS, and Université P \& M Curie, F-29211 Roscoff, France \\ ${ }^{2}$ Laboratoire de Chimie Analytique, Faculté des Sciences, F-64000 Pau, France
}

\begin{abstract}
Organic copper-complexing agent released by the snail Hydrobia uivae was characterized by Differential Pulse Anodic Stripping Voltammetry (DPASV) after incubation of the snails in natural or synthetic sea water. The Cu(II) association constant (i.e. apparent equilibrium constant log $\mathrm{K}^{\mathrm{app}}=8.1$ ) of the ligand excreted is close to the apparent stability constant of naturally occurring humates. The effects of incubation time, snail densities, initial complexing capacity and initial copper content of the incubation medium were studied. The results show that a stable maximum ligand concentration level of $198 \pm 14 \mathrm{nmol}^{-1}$ was reached in all cases where snail density was higher than 1000 organisms $1^{-1}\left(36000 \mathrm{org} \mathrm{m}^{-2}\right)$. These results strongly suggest the existence of an active regulation of cation activity in seawater by $H$. ulvae, and are analogous to literature data dealing with regulation of primary amine concentrations by these animals.
\end{abstract}

\section{INTKODUCTIÓN}

In natural waters, the activity of living organisms influences the chemistry of the surroundings. In return, metabolic activities of aquatic organisms may be depressed or enhanced by changes in the chemical composition of the aquatic environment. In open oceans, where space-time scales are large and geochemical stability is strong, this interactive model has been known for a long time as the 'Redfield model', based upon the variations in the major nutrient elements, carbon, nitrogen, phosphorus and oxygen, in seawater. More recently, this model has been extended fruitfully to several trace elements, many of which are not essential micronutrients (reviewed by Morel \& Hudson 1984). In coastal systems, biological processes are often concealed at middle and large scales by the complex variations that characterize these environments. However, if the notion of microenvironment (defined by scales extending beyond meters and hours to millimeters and minutes) is considered, it is possible to reveal the influence of biogenic substances, which are below classical in situ detection limits, on the chemistry of the coastal waters (e.g. Goldman 1984).
Many aquatic organisms release metal-complexing agents. Most of the data originate from phytoplankton (McKnight \& Morel 1979, 1980) and bacterial studies (Neiland 1981). Macrophytes (Sueur et al. 1982), and recently zooplankton (Fish \& Morel 1983) have also been found to produce ligands, but studies concerning meiofauna or small epifauna are scarce and focus on mucus production as a possible mechanism influencing the uptake and loss of trace metals (Howell 1982).

The work presented here explores how a minute epibenthic detritus feeder, Hydrobia ulvae (Gastropoda: Prosobranchia), can alter the speciation of trace metal by releasing complexing agents into the water

Hydrobiids are small gastropods belonging to the important deposit-feeding invertebrates of Northern European and American estuaries and lagoons. These 2 to $7 \mathrm{~mm}$ long snails occur at the surface and subsurface of nearly all shallow water sediments. Densities of 50000 organisms m$~^{-2}\left(\mathrm{org} \mathrm{m}^{-2}\right)$ are frequent (Fenchel 1975, Kofoed 1975a). They feed on bacteria attached to sand grains and vegetal detritus and on microalgae (Newell 1965, 1970, Fenchel 1975, Fenchel et al. 1975, Lopez \& Levinton 1978, Levinton \& Bianchi 1981) and present an important bioturbating activity. Hydrobia 
spp. are known to excrete a considerable part of assimilated carbon as dissolved organic material $(30 \%)$, and the secretion of mucus constitutes about $9 \%$ of the assimilated carbon; an important loss of dissolved matter results from leakage from faecal pellets (Kofoed 1975b). Due to the large population densities of this snail, which is associated with a very broad fundamental niche, mainly shallow waters from 0 to $35 \%$ salinity (for the 3 species $H$. uvae, $H$. neglecta and $H$. ventrosa), the release of this dissolved organic matter could make a contribution to the total pool of autochthonous complexing organic compounds.

\section{MATERIAL AND METHODS}

Hydrobia ulvae (Pennant) were collected in the 'Aber de Roscoff', a $2 \mathrm{~km}$ long sound with muddy-sand sediment, on the North Brittany coast, France (e.g. Rullier 1959). The Aber is submerged at each high tide (twice a day), and water depth is less than $1 \mathrm{~m}$. Snail densities range between 6000 and $30000 \mathrm{org} \mathrm{m}^{-2}$.

The snails were maintained several weeks at the laboratory. They were kept in 21 glass beakers containing $30 \% \mathrm{~S}$ seawater and $5 \mathrm{~mm}$ sediment, and maintained at $12^{\circ} \mathrm{C}$ in an illuminated thermostated incubator. The seawater was renewed from time to time and mortality was very low (less than $2 \%$ ).

Before each experiment, the snails were removed from the sediment, rubbed on blotting paper until most of the epiphytes were removed, and starved several hours in filtered seawater. Hydrobia ulvae were then incubated in glass vessels containing 1 I natural seawater (NSW), synthetic sea water (SSW, see Table 1), or NSW + sediment.

Table 1. Composition of synthetic sea water $\left(\mathrm{mol} \mathrm{l}^{-1}\right)$

\begin{tabular}{ll|}
\hline $\mathrm{NaCl}$ & $4.7 \times 10^{-1}$ \\
$\mathrm{SO}_{4} \mathrm{Mg} .7 \mathrm{H}_{2} \mathrm{O}$ & $2.8 \times 10^{-2}$ \\
$\mathrm{Cl}_{2} \mathrm{Mg} .6 \mathrm{H}_{2} \mathrm{O}$ & $2.6 \times 10^{-2}$ \\
$\mathrm{KCl}$ & $9.4 \times 10^{-3}$ \\
$\mathrm{CO}_{3} \mathrm{HNa}$ & $2.5 \times 10^{-3}$ \\
$\mathrm{CaCl}_{2}$ & $1.2 \times 10^{-2}$ \\
\hline
\end{tabular}

All apparatus was acid-washed in $4 \mathrm{~N} \mathrm{HNO}_{3}$ and the chemicals used were reagent grade (Suprapur, Merck). Seawater filtrations were performed on $0.22 \mu \mathrm{m}$ acidwashed filters (Millipore YY 42 14200) under low pressure.

Metal-organic interactions in natural seawater, $0.22 \mu \mathrm{m}$ filtered seawater and seawater incubated with Hydrobia ulvae were measured using increasing amounts of total copper added to the solution at natural pH (8.25), controlled by an Ingold electrode. Reducible copper was measured by Differential Pulse Anodic
Stripping Voltammetry (DPASV) with hanging mercury drop electrode (Metrohm, E626, E627 and E608, Switzerland) (Campbell et al. 1977. Hauck \& Dillard 1977, McCrady \& Chapair 1978, Hart \& Davies 1981, Truitt 1981, Tuschall \& Brezonik 1981, Shuman 1982, Jardin \& Pearson 1984).

The DPASV method for determining 'reducible' cations (i. e. cations not bound or weakly bound to organic and inorganic ligand) in solution consists of 2 succesive phases:

(1) The plating phase : in order to increase the concentration of reducible cations at the surface of the working anode (a hanging drop of mercury), an electrolytic voltage is applied to the medium (e. g. seawater). As a result of the electrolysis, the reducible cations in solution combine with the mercury surface. The amount of plated cations is proportional to the concentration of reducible cations in solution and to the experimental conditions (electrolysis time, voltage, shape of the working electrode).

(2) The determination phase : a sweeping voltage is progressively applied between the mercury electrode and the cathode, from negative to positive values. The range of the electric sweeping depends on the cation to be measured (e. g. from -400 to $+100 \mathrm{mV}$ for copper determination). As a result of this electrical sweeping, the previously plated cations are specifically oxidized. During the oxidation phase, the peak intensity (nanoAmpere) of the electrical current measured between the cathode and the anode is proportional to the amount of the plated cations. Using known copper dilutions, the relation between peak intensity and reducible copper in solution is established.

Experimental conditions were: electrolysis voltage $-400 \mathrm{mV}$ ( Ag/ $\mathrm{AgCl}$ saturated $\mathrm{KCl}$ reference), electrolysis time $120 \mathrm{~s}$, rest period $30 \mathrm{~s}$, differential voltage sweep from $-400 \mathrm{mV}$ to $+100 \mathrm{mV}$ in steps of $5 \mathrm{mV} \mathrm{s}^{-1}$, pulse voltage $50 \mathrm{mV}$, with a frequency of $1 \mathrm{~Hz}$. The ion-selective electrode technique was not suitable for our studies because of the high salinity of the water (Westall et al. 1979).

When free ligand concentrations are to be determined, increasing amounts of total copper are added to the medium, and the appearance of reducible copper is checked using DPASV (Fig. 1). The equilibrium between the hypothetically unique organic ligand $\mathrm{L}$ and copper in solution is defined by the relation

$$
\mathrm{Cu}_{\mathrm{i}}+\mathrm{L} \rightleftarrows \mathrm{CuL}\left(\mathrm{K}^{\mathrm{app}}\right)
$$

characterized by the apparent equilibrium constant $\left(\mathrm{K}^{\mathrm{app}}\right)$, where $\mathrm{Cu}_{1}=$ total concentration of inorganic copper species in solution (free aqueous ion + DPASVlabile inorganic complexes). Polynuclear complexes are, however, unlikely at these low concentrations. 
From amperometric (DPASV) copper titration curves of seawater samples (Fig. 1) the total concentration of the organic ligand $\mathrm{L}_{\mathrm{T}}^{0}$ and the value of $\left(\mathrm{K}^{\mathrm{app}}\right)$ were evaluated by graphic resolution of a Ruzic plot of the data, modified to take into account the non-negligible initial concentration of copper $\left(\mathrm{Cu}_{\mathrm{T}}^{\mathrm{o}}\right)$, as follows:

$$
\frac{\left(\mathrm{Cu}_{1}\right)}{\left(\mathrm{Cu}_{\mathrm{T}}^{o}\right)+\left(\mathrm{Cu}_{\mathrm{a}}\right)-\left(\mathrm{Cu}_{\mathrm{i}}\right)}=\frac{\left(\mathrm{Cu}_{\mathrm{i}}\right)}{\mathrm{L}_{\mathrm{T}}^{o}}+\frac{1}{\left(\mathrm{~K}^{\mathrm{app}}\right) \times \mathrm{L}_{\mathrm{T}}^{o}}
$$

where $\left(\mathrm{Cu}_{\mathrm{a}}\right)$ expresses the copper additions. Ligand concentrations are expressed as complexing capacity (CC).

Total copper determinations were performed for natural seawater, sediment and Hydrobia ulvae populations after acid digestion. Seawater was evaporated in the presence of $\mathrm{H}_{2} \mathrm{O}_{2}$ after acidification by $\mathrm{HNO}_{3}$; the dry residue was redissolved in $\mathrm{Q}$-water (metal-free deionized water, Millipore) and titrated by DPASV. Sediment and $H$. ulvae were mineralized after dry weight determination: samples $(1 \mathrm{~g})$ were oxidized $3 \mathrm{~h}$ at $550^{\circ} \mathrm{C}$. The ash was then attacked in Teflon vials with $10 \mathrm{ml} \mathrm{HCl} 30 \%$ and $10 \mathrm{ml} \mathrm{HF} 48 \%$ and the mixture was evaporated. This operation was repeated 3 times. The dry residue was then dissolved in $1 \mathrm{ml}$ hot $\mathrm{HNO}_{3}$ and a few $\mathrm{ml}$ of deionized water, filtered on Whatman no. 41 , adjusted to $10 \mathrm{ml}$ and titrated by DPASV (Marchandise et al. 1981, Welte et al. 1983).

Population density and incubation time effects were studied by collecting the excretion of 100,500,1000, 1500 and 10000 Hydrobia ulvae $\mathrm{l}^{-1}$ after 1 to $15 \mathrm{~d}$ incubation periods in natural and synthetic seawater. The blank consisted of natural seawater. For the other experiments, a density of $1000 \mathrm{H}$. ulvae $\mathrm{l}^{-1}$ (36 000 org $\mathrm{m}^{-2}$ ) was chosen. This density is close to maximum field density and did not induce major crowding effects on $H$. ventrosa behaviour (Levinton 1979).

The decay rate over $2 \mathrm{~d}$ was studied on collected excretions in natural and synthetic seawater.

To test the effect of Hydrobia ulvae excretion on copper speciation, copper sulfate was added to vessels of synthetic seawater (SSW), natural seawater (NSW), or NSW and sediment, with or without $H$. ulvae. Total copper was added at concentrations of $0.157,1.57,7.85$ and $15.70 \mathrm{~mol} \mathrm{l}^{-1}\left(10,100,500\right.$ and $\left.1000 \mu \mathrm{g} \mathrm{l}^{-1}\right)$. Complexation capacity (CC) was checked immediately (15 min) after and $3 \mathrm{~d}$ after the copper addition; total copper in NSW and in snails was measured after $3 \mathrm{~d}$.

\section{RESULTS}

The total ligand concentration evaluated from Ruzic plots in NSW at the Roscoff station varied in the range
$\mathrm{L}_{\mathrm{T}}^{\mathrm{O}}=100$ to $130 \mathrm{nmol}^{-1}$. In the example given (Fig. 1), the mathematical treatment of the data leads to an $L_{T}^{0}$ of $118 \pm 7 \mathrm{nmol} \mathrm{l}^{-1}$, of which $30 \pm 7 \mathrm{nmol} \mathrm{l}^{-1}$ was engaged in a copper complex, the remaining free ligand $(\mathrm{CC})$ being $88 \pm 14 \mathrm{nmol} \mathrm{l}^{-1}$. This value is to be compared to that obtained by direct reading on the amperometric titration curve (Fig. 1): $99 \pm 7 \mathrm{nmol} \mathrm{l}^{-1}$.

About $25 \%$ of this CC was related to particulate matter retained on $0.22 \mu \mathrm{m}$ pore-size filters (Fig. 1). The organic carbon responsible for the dissolved $\mathrm{CC}$ was probably humic acids (Mantoura et al. 1978) binding copper with an apparent stability constant $\log \mathrm{K}^{\mathrm{app}}$ in the range 7.2 to 7.9 at $\mathrm{pH} 8.2$ for the samples studied. At $\mathrm{pH} 5$, the natural $\mathrm{CC}$ of seawater disappears, when combination between ligand and protons becomes preponderant (Duursma \& Sevenhuysen 1966, Odier \& Plichon 1971, Heyrovsky \& Vavricka 1972, Zirino \& Yamamoto 1972, Hahne \& Kroontje 1973).

Total copper concentration was $39 \mathrm{nmol} \mathrm{l}^{-1}$ in seawater and $39 \mathrm{nmol} \mathrm{g}^{-1}$ dry weight in sediment.

The complexing capacity of $1 \mathrm{lNSW}$ into which 1000 Hydrobia ulvae had been introduced increased rapidly and in 15 to 20 min reached a reproducible maximum value of $198 \pm 14 \mathrm{nmol}^{-1}$. This value was stable as long as the snails were allowed to remain in the medium (up to 15 d, Fig. $2 \& 3$, Table 2). This maximum value is not significantly different from 500 to $10000 \mathrm{org} \mathrm{l}^{-1}$ (for long-term experiments: Fig. 4).

During the phase of increasing $\mathrm{CC}$, ligand produc-

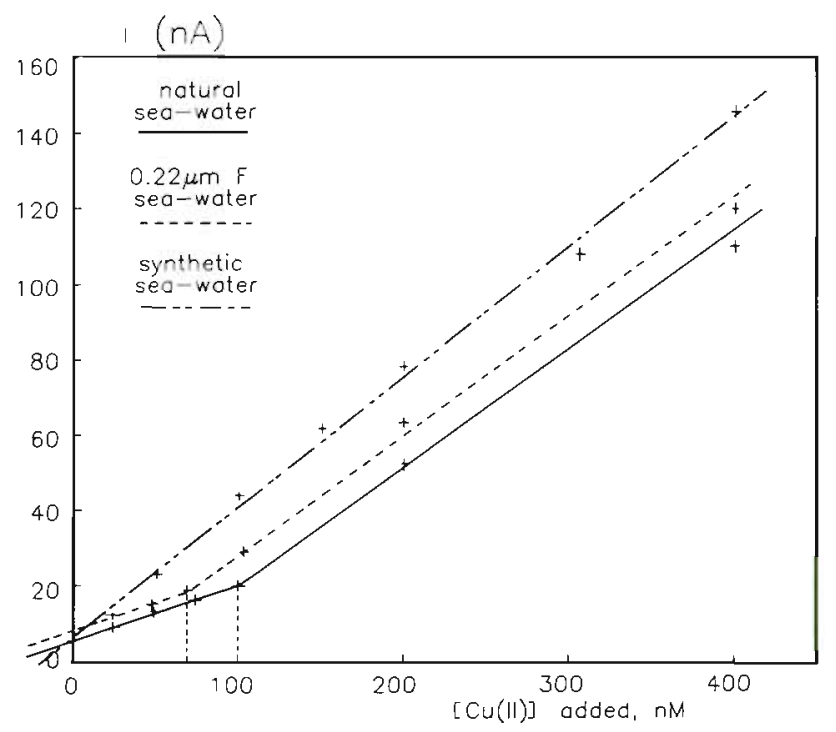

Fig. 1. DPASV titration curves of $\mathrm{Cu}(\mathrm{II})$ in synthetic and natural seawater $(\mathrm{pH} \mathrm{8.25)}$. Y-axis: peak intensity of electrical current generated during inverse voltage sweeping. This intensity is proportional to free $\mathrm{Cu}(\mathrm{II})$ in solution. $\mathrm{X}$-axis: successive amounts of total copper $\left(\mathrm{CuSO}_{4}\right)$ added to the medium. Break-point corresponds to disappearance of the complexing capacity of the medium (all ligand bound by the copper additions) 


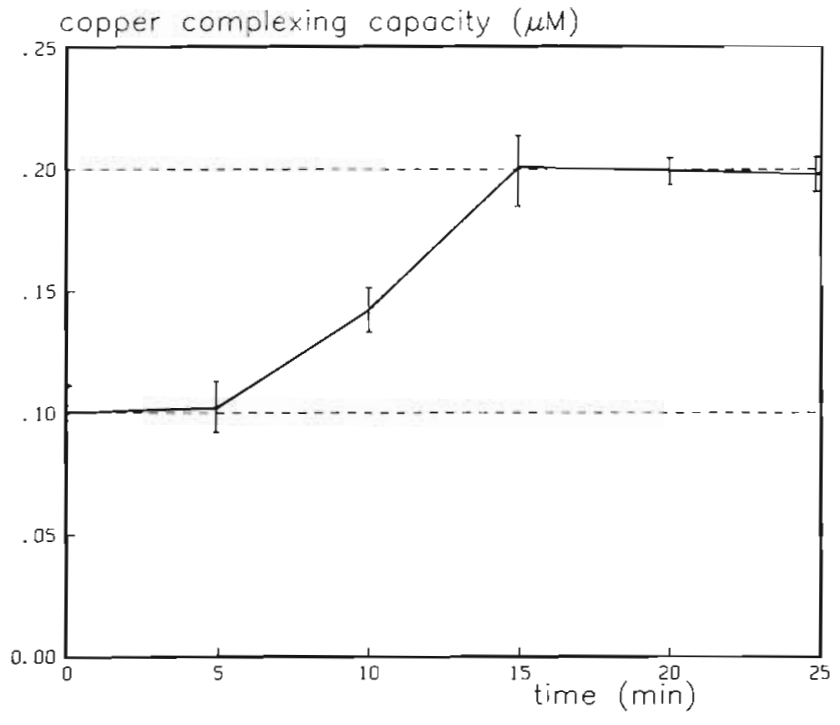

Fig. 2. Short-term variation of natural seawater copper-complexing capacity in presence of a population of Hydrobia uvae $\left(1000 \mathrm{org}^{-1}\right.$ or 3.6 org $\left.\mathrm{cm}^{-2}\right)$

tion rate was ca $1 \mathrm{pmol} \mathrm{org}^{-1} \mathrm{~h}^{-1}$ for 100 and 500 org $\mathrm{l}^{-1}$ and for incubation times varying from 1 to 8 and $15 \mathrm{~d}$. At higher snail densities, production is apparently stimulated and reached 246 to $392 \mathrm{pmol}$ $\operatorname{org}^{-1} \mathrm{~h}^{-1}$ for incubation times from 15 to $30 \mathrm{~min}$. These data are, however, subject to further enquiry as the experiments were not directly designed to measure production rates. In particular, the homogeneity of the medium was not certain during the first minutes of incubation.

In SSW, the initial CC was zero. In spite of this, the maximum ligand concentration reached in the presence of 1000 and 1500 org $^{-1}$ was still 193 $\pm 11 \mathrm{nmol}^{-1}$. This maximal value thus was not significantly affected by the difference between initial CC in NSW and SSW.

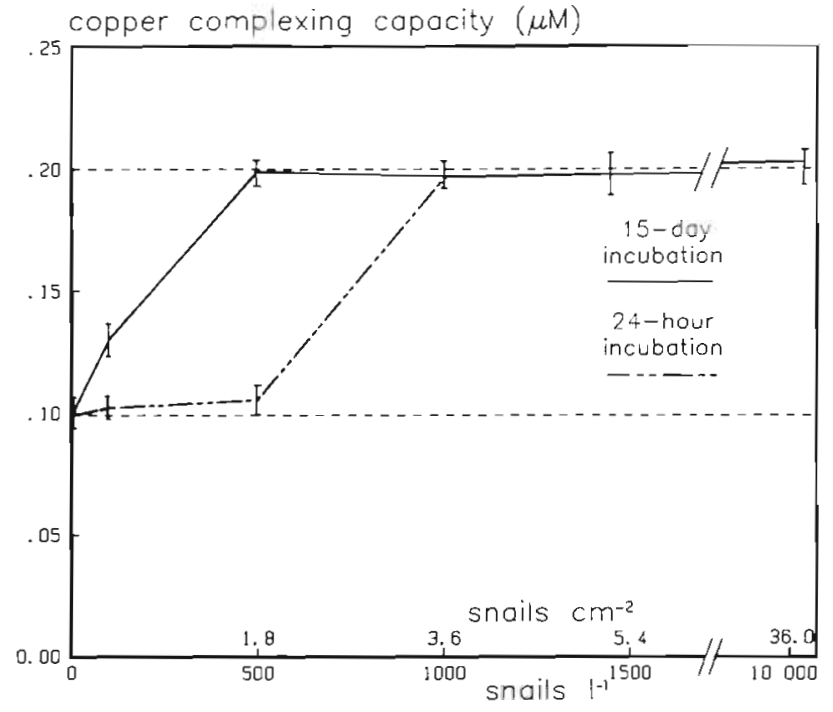

Fig. 3. Variation of natural seawater copper-complexing capacity as function of incubation time in presence of different Hydrobia ulvae densities

The determination of the $\mathrm{Cu}(\mathrm{II})$ association constant of the organic ligand excreted by Hydrobia ulvae was performed after incubation in SSW. The value obtained

$$
\log \mathrm{K}^{\mathrm{app}}=8.1
$$

is close to the apparent stability constant of the humic acids present in NSW and titrated under the same experimental conditions.

These experiments were performed without control of bacterial growth (in presence of the snails). However, contribution of associated bacteria to ligand production is assumed not to be significant, as shown by Fish \& Morel (1983) using collections of Daphnia magna secretions in axenic and non-axenic cultures. Moreover, in NSW (control without snails and com-

Table 2. Evolution of the complexing capacity $\mathrm{L}^{\circ}$ of the water after a single copper addition in experimental microcosms of different compositions. Total copper was measured in the NSW + snails microcosms

\begin{tabular}{|c|c|c|c|c|c|c|c|c|c|}
\hline \multirow{3}{*}{$\begin{array}{l}\mathrm{Cu}(\mathrm{II}) \\
\text { adds }\end{array}$} & \multirow{3}{*}{$\begin{array}{l}\text { Time } \\
\text { after } \\
\text { add. }\end{array}$} & \multirow{3}{*}{$\begin{array}{c}\text { Synthetic } \\
\text { seawater } \\
\text { (SSW) }\end{array}$} & \multicolumn{4}{|c|}{ Copper complexing capacity Lo (nmol l-1) } & & \multicolumn{2}{|c|}{ Total copper } \\
\hline & & & Natural & NSW + & & Hydro & $1^{-1}$ & in $10^{3}$ & in 11 \\
\hline & & & $\begin{array}{l}\text { seawater } \\
\text { (NSW) }\end{array}$ & sediment & SSW & NSW & $\begin{array}{l}\text { NSW + } \\
\text { sediment }\end{array}$ & $\begin{array}{c}\text { Hydrobia } \\
(\mu \mathrm{mol})\end{array}$ & NSW \\
\hline \multirow{2}{*}{0} & $15 \mathrm{~min}$ & 0 & 99 & 92 & 192 & 197 & 192 & & \\
\hline & $3 \mathrm{~d}$ & 0 & 96 & 104 & 196 & 208 & 196 & 3.97 & $40 \mathrm{nmol}$ \\
\hline \multirow{2}{*}{$157 \mathrm{nM}$} & $15 \min$ & 0 & 0 & 0 & 104 & 92 & 102 & & \\
\hline & $3 d$ & 0 & 0 & 100 & 198 & 204 & 204 & 4.15 & $38 \mathrm{nmol}$ \\
\hline \multirow{2}{*}{$1.57 \mu \mathrm{M}$} & $15 \mathrm{~min}$ & 0 & 0 & 0 & 0 & 0 & 0 & 5.56 & $\pm 40 \mathrm{nmol}$ \\
\hline & $3 d$ & 0 & 0 & 0 & 0 & 0 & 192 & & \\
\hline $7.85 \mu \mathrm{M}$ & $3 d$ & \multicolumn{6}{|c|}{$L_{-\uparrow}^{0}=0$} & 9.12 & $3.02 \mu \mathrm{mol}$ \\
\hline $15.70 \mu \mathrm{M}$ & $3 d$ & \multicolumn{6}{|c|}{$\mathrm{L}_{\mathrm{T}}^{o}=0$} & 12.38 & $6.86 \mu \mathrm{mol}$ \\
\hline
\end{tabular}




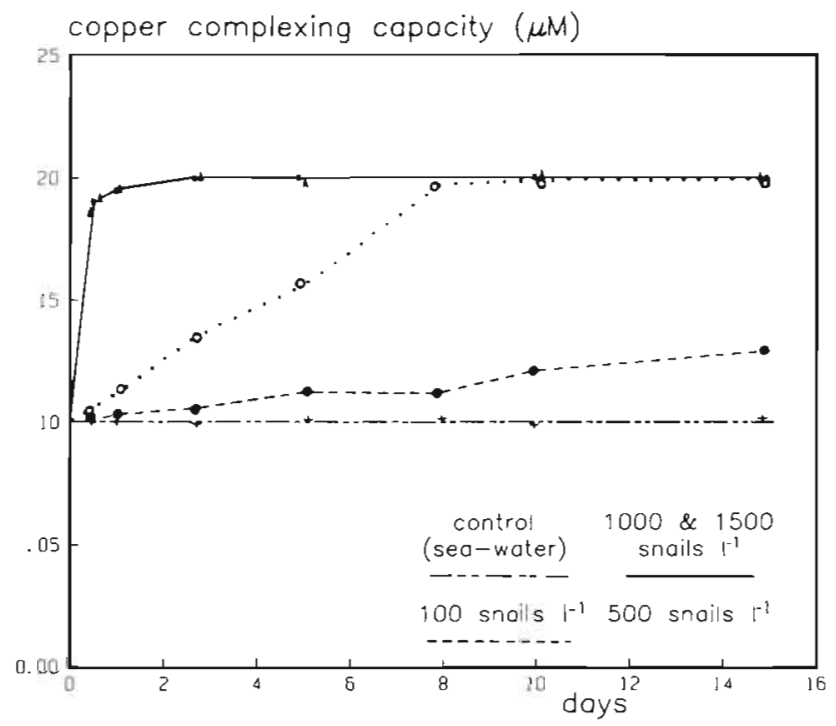

Fig. 4. Variation of natural seawater copper-complexing capacity as function of Hydrobia ulvae density during medium and long-term incubation experiments

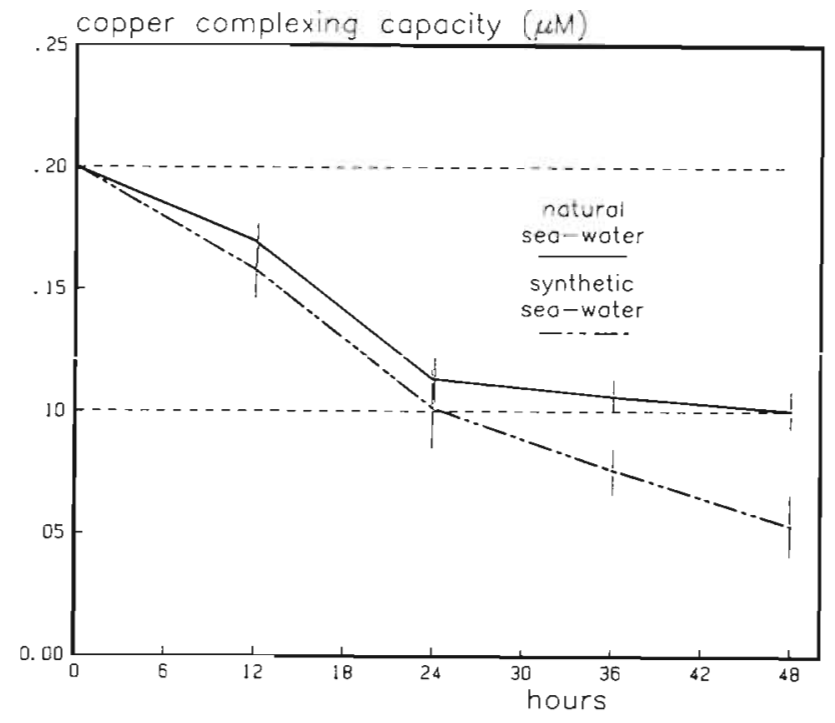

Fig. 5. Time-lability of the copper-complexing capacity generated by Hydrobia ulvae in natural and synthetic sea water after removal of the snails from the incubation medium $\left(12^{\circ} \mathrm{C}\right)$

plementary experiment in presence of amino acids), the initial CC remained unchanged with time, in spite of a marked increase of bacterial biomass.

In Fig. 5, the decay rates of collected excretions of $1000 \mathrm{org}^{-1}$ in NSW and SSW are shown as evaluated by titrations during the $48 \mathrm{~h}$ after snails were removed. After snail removal, both in NSW and SSW, the CC decreased slowly (when compared to ligand production rates) over $24 \mathrm{~h}$. This decrease may be the result of biological degradation of the ligand excreted by $H y$ drobia ulvae. Heterotrophic bacterial strains using this organic molecule as growth substrate could be responsible for such degradation. These bacteria are autochthonous in NSW and are introduced with the snails when the medium is SSW. This associated bacterial population, attached to the snail shells and colonising the guts, continues to grow in SSW on H. ulvae excretions, mucus, and faecal pellets produced on mucus reingestion

After this $24 \mathrm{~h}$ period, the CC showed a tendency to stabilize. The decrease of the $\mathrm{CC}$ was reduced and ceased after $48 \mathrm{~h}$ in NSW on return to the initial value $\left(99 \pm 11 \mathrm{nmol}^{-1}\right)$. The remaining $\mathrm{CC}$ was related to seawater humates which are resistant to further breakdown.

In SSW, a fraction of the ligand $\left(47 \pm 7 \mathrm{nmol}^{-1}\right.$ ) remained at the end of the experiment and was apparently refractory. This remaining $\mathrm{CC}$ observed $48 \mathrm{~h}$ after snail removal could be due to contamination by humates during the transfer of Hydrobia ulvae from NSW to SSW, or to structural modifications of a part of the excreted ligand (through bacterial metabolism).

In Table 2 , the residual complexing capacity of the seawater measured $15 \mathrm{~min}$ and $3 \mathrm{~d}$ after the addition of $157 \mathrm{nmol} \mathrm{l}^{-1}$ (nM), $1.57 \mu \mathrm{M}, 7.85 \mu \mathrm{M}$, and $15.7 \mu \mathrm{M}$ copper is indicated for different experimental conditions. The copper additions were performed in

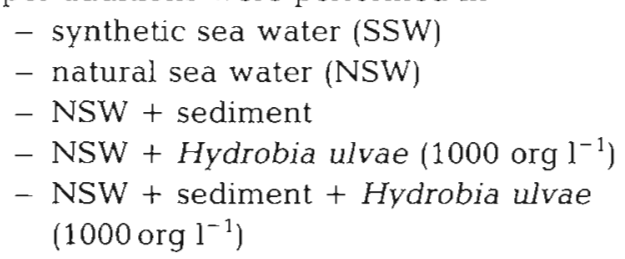

In NSW, a $157 \mathrm{nM}$ copper addition was sufficient to bind all the free ligand in solution $\left(99 \pm 11 \mathrm{nmol} \mathrm{l}^{-1}\right.$ ). The copper was in excess and the residual CC was not measurable. Three days after the copper addition, copper was still in excess in the sea water.

In NSW + sediment, the tree ligand present in the water was rapidly complexed by the addition of copper, and the $\mathrm{CC}$ measurements $15 \mathrm{~min}$ after copper addition indicate an excess of copper. However, for $157 \mathrm{nM}$ copper added, the $\mathrm{CC}$ was regenerated after $3 \mathrm{~d}$ because the initial free copper in the water (excess copper) had become trapped in the sediment. It is assumed that copper is exchanged from the dissolved ligand to the sediment. For higher copper additions, the regeneration of the seawater $\mathrm{CC}$ was not reached after $3 \mathrm{~d}$ incubation.

When Hydrobia ulvae are present, in SSW, in NSW and in NSW + sediment, the initial CC was equivalent to $198 \pm 14 \mathrm{nmol} \mathrm{l}^{-1}$. A DPASV titration $15 \mathrm{~min}$ after $157 \mathrm{nM}$ copper addition indicated that the residual CC was about $100 \mathrm{nmol} \mathrm{l}^{-1}$. This value is higher than expected $\left(198-157=41 \mathrm{nmol} \mathrm{l}^{-1}\right)$. This extra CC may be due to different factors. For example, only part of the $157 \mathrm{nM}$ copper added to the system is bound by 
the dissolved ligand; the remaining part may be directly adsorbed by the container walls and chiefly by the $H$. uvae shells and particulate mucus secreted by the snails. This hypothesis is corroborated by the total copper measurement after $H$. ulvae mineralization: after $3 \mathrm{~d}$, all the copper added had been absorbed by or adsorbed onto the snails (Table 2). Alternatively, during the $15 \mathrm{~min}$ incubation before titration, the $H$. ulvae could have produced extra organic ligand (as a response to copper addition) contributing to an increase of the residual CC. These 2 hypotheses implicate an apparent or real excess in ligand concentration.

After $3 \mathrm{~d}$, the approximate $200 \mathrm{nmol}^{-1}$ initial $\mathrm{CC}$ was restored. Determination of total copper in snails and NSW shows that the dominant process of copper removal is, in the middle-term, adsorption or assimilation by the Hydrobia ulvae.

At $1.57 \mu \mathrm{M}$ copper addition, $\mathrm{CC}$ recovery was observed after $3 \mathrm{~d}$ when Hydrobia ulvae and sediment were present. In the absence of snails, the copper was still in excess $3 \mathrm{~d}$ after copper addition. In the presence of snails, without sediment, the CC was still zero $3 \mathrm{~d}$ after copper addition, but total copper in seawater was close to its natural value $\left(40 \mathrm{nmol}^{-1}\right)$ and all the copper added was found in the snails. Although longer-term experiments were not performed, we presume that $\mathrm{CC}$ recovery occurs after all extra copper is transferred from seawater to the snail bodies or to the sediment. Copper concentrations higher than $1.57 \mu \mathrm{mol} \mathrm{I}^{-1}$ are lethal for $H$. ulvae, and only a part of the copper added is found in the snails (Table 2).

\section{DISCUSSION AND CONCLUSION}

The experimental introduction of Hydrobia ulvae to natural and synthetic seawater increases the natural copper-complexing capacity of these media. This increase of $\mathrm{CC}$ probably results from the excretion by the snails of a dissolved chelating agent. The apparent complexation constant of this ligand $\left(\log \mathrm{K}^{\mathrm{app}}=8.1\right)$ is close to the values obtained under the same conditions for the humates of the NSW.

The nature of the ligands excreted by marine organisms is poorly known. Hydrobiids excrete various compounds that may account for this CC: ammonia, amino acids, polysaccharides and peptides (Kofoed 1975b, Pandian 1975). The very low binding capacity of ammonia and amino acids excludes these compounds (Gardner \& Miller 1981, Fish \& Morel 1983). The affinity of mucus for metals has been noted for various fish species (Carpenter 1927, McKone et al. 1971, Varanasi et al. 1975) and invertebrates (Howell 1982). However, mucus is secreted as particulate rather than dissolved matter. Although an eventual role of the mucus excre- tion cannot be discarded in the increase of dissolved CC observed in the presence of snails, we do not believe that particulate mucus could be collected when water was sampled for titration.

In all experiments, the release of ligand by Hydrobia ulvae at densities $\geq 1000$ org $\mathrm{l}^{-1}(1667 \mathrm{mg}$ wet weight with shells) increased the $\mathrm{CC}$ to about $200 \mathrm{nmol} \mathrm{l}^{-1}$ within the first $20 \mathrm{~min}$. This concentration was maintained for at least $15 \mathrm{~d}$ in presence of the snails. When an initial concentration of 0.157 to $1.57 \mu \mathrm{M}$ copper was added, this $200 \mathrm{nmol}^{-1}$ level was re-established in less than $3 \mathrm{~d}$.

Very similar results were obtained by Jørgensen (1980) with primary amines (i.e. amino acids) released by Hydrobia neglecta. In this work, the author observed that $30 \mathrm{H}$. neglecta $/ 10 \mathrm{ml}$ (1032 $\mathrm{mg}$ wwt with shells per l) released $5 \mu \mathrm{mol} \mathrm{I}^{-1}$ primary amines within the first hour of incubation and that this steady state was maintained at least from $24 \mathrm{~h}$ to $4 \mathrm{~d}$. Even when $50 \mu \mathrm{M}$ glycine was added, this level of $5 \mu \mathrm{mol} \mathrm{l}^{-1}$ was reestablished in $24 \mathrm{~h}$. Corresponding results were obtained with the polychaete Nereis virens by the same author. Similar results also were reported by Wright \& Stephens (1978) for the bivalve Mytilus californianus and by Stephens et al. (1978) for the sand dollar Dendraster exentricus. These authors suggest that this steady state is the result of a balance between influx and efflux of primary amines by the animals and may be explained by uptake of primary amines released by the animals.

The agreement between our results and those described suggests that a similar mechanism could regulate the concentration of ligand excreted by $\mathrm{Hy}$ drobia ulvae. This mechanism could account for the accumulation of copper in the snails, via the re-assimilation of the organometallic complex resulting from the combination of free metal and the excreted ligand. A parallel mechanism of copper bioaccumulation in the marine nematodes through mucus complexation is proposed by Howell (1982).

However, this model does not account for the fact that in the presence (in NSW) and in the absence of humic material (in SSW), the total CCs were equivalent. This situation corresponds to excreted ligand concentrations of about $99 \pm 11$ and $198 \pm 14 \mathrm{nmol}^{-1}$ respectively, suggesting that regulation is controlled by the activity of some cation (i.e. free cation concentration). In this case, we must presume that the approximately 200 $\mathrm{nmol} \mathrm{l}^{-1} \mathrm{CC}$ steady state observed is in fact the result of an active process where the cation activity plays the role of a negative feed-back loop on the influx-efflux balance in the snails. The total concentration of ligand, independently of the type of the ligand, could play the same role. It is not possible to give a definitive opinion on this problem with the current state of the knowledge. 
Table 3. Average complexing capacity, complexation constant and total copper content of seawater and sediment at 3 coastal locations. Recapitulation of data concerning Hydrobia Uvae at Roscoff location. NSW: natural seawater; SSW: synthetic seawater; org: organism

\begin{tabular}{|c|c|c|c|c|}
\hline \multicolumn{3}{|c|}{ Complexing capacity ( $\mathrm{nmol} \mathrm{L^{-1 }}$ ) } & \multicolumn{2}{|c|}{ Total copper } \\
\hline In natural seawater & In 0.22 um seawater & $\log K^{\mathrm{dpp}}$ & Seawater $\left(\mathrm{nmol} \mathrm{l}^{-1}\right)$ & Sediment $\left(\right.$ nmol $\left.g^{-1}\right)$ \\
\hline \multicolumn{5}{|l|}{ Arcachon } \\
\hline 220 & 175 & 7.5 & 122 & 64 \\
\hline \multicolumn{5}{|l|}{ La Teste } \\
\hline 400 & 210 & 7.1 & 39 & 192 \\
\hline \multicolumn{5}{|l|}{ Roscoff } \\
\hline 99 & 78 & 7.9 & 40 & 40 \\
\hline \multicolumn{5}{|c|}{ 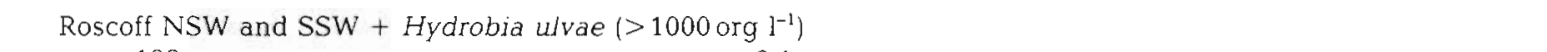 } \\
\hline \multirow{4}{*}{198} & Average Hydrobia ul & data (Roscoff & & \\
\hline & In situ densities & $6000-3000$ & & \\
\hline & Weight (with shells) & $\left\{\begin{array}{r}1667 \mathrm{mg} / 100 \\
998 \mathrm{mg} / 10 \mathrm{o}\end{array}\right.$ & $\begin{array}{l}\text { weight } \\
\text { weight }\end{array}$ & \\
\hline & Copper content & $3.8 \mu \mathrm{mol} / 100$ & & \\
\hline
\end{tabular}

From our results, copper could be the cation responsible for the regulation process, but implication of other polyvalent cations (e.g. $\mathrm{Fe}^{3+}$ ) cannot be discarded.

In Table 3, results are given for the Roscoff station and for 2 lagoon locations on the French Atlantic coast: a muddy sand (Arcachon) and a mud (La Teste) (El Mednaoui et al. 1984). Sediments at Arcachon and Roscoff locations are similar. The differences in total copper concentrations at these 2 stations probably are a reflection of intensive human activity in Arcachon (chiefly mariculture and navigation, both using copper compounds for antifouling treatment). Total copper concentration for all these stations is much higher in sediment than in water. This fact demonstrates the wellknown trapping and regulatory capacity of the sediment (Rashid 1974, Pesch \& Morgan 1978). However, the concentration of copper is much higher in freshly collected snails $\left(3.8 \mu \mathrm{mol} \mathrm{g}^{-1} \mathrm{dw}\right)$ than in the sediment $\left(\leq 0.19 \mu \mathrm{mol} \mathrm{g}{ }^{-1} \mathrm{dw}\right)$. At the Roscoff station, the total copper carried by these organisms would reach up to $7.5 \mathrm{mg} \mathrm{m}^{-2}$ for an average density of $30000 \mathrm{org} \mathrm{m}^{-2}$. Taking into account the high densities and the broad distribution of the hydrobiids, we suggest that metal speciation in coastal systems could be significantly modified by the presence of these organisms. Other epibenthic species probably play a similar role.

We can assume that both mucus production and dissolved organic ligand play a role in the processes of copper bioaccumulation. Reingestion of mucus by Hydrobia ulvae is a well-known feeding behaviour, which can be implicated in absorption and fixation of trace metals previously bound by the mucopolysaccharide molecule. On the other hand, the presence of organic ligand has been shown to enhance both the bioaccumulation rate and final concentration of trace metals in the tissues of other marine species (George \& Coombs 1977, Noël-Lambot et al. 1981).

From the literature data, it appears that production of bioligands is a common feature in the marine environment. Some of these ligands are specific complexing molecules, like siderophores, presenting a high affinity for iron. However, in various cases, the moderate association constants of these organic assemblages are very close to the characteristics of naturally occurring humic acids, and suggest that their complexing capacity could be a secondary feature. Nevertheless, the ecological role of these ligands may be important in the processes of trace metal assimilation, in the open ocean, where they are produced by phyto- and zooplankton, and in coastal systems, where the watersediment interface and the living organisms colonizing this boundary layer greatly influence the chemical and biological processes of the overlying waters. In the process of bioaccumulation, we suggest that the role of such weak or moderate organic ligands is related, at least in part, to their biological availability. In this regard, they may be contrasted with humic acids, which as organic residues are resistant to further breakdown. In the present case, with the exception of the capacity to decrease free cation activity in seawater, the role of the chelating compounds released by Hydrobia ulvae cannot be defined with precision, and the mechanisms and ecological significance of their regulation remain in question.

Acknowledgements. We are most grateful to Professor Michel Astruc and Dr. Alain Castetbon, from the Laboratoire de Chimie Analytique, Université de Pau (France); to Professor 
François Morel and Ms Janet Herring, from the M. Parson Laboratory, Massachusetts Institute of Technology (USA); to Professor Pierre Lasserre, Station Biologique de Roscoff (France); and to 3 anonymous advisors for valuable and constructive comments.

\section{LITERATURE CITED}

Campbell, P. G. C., Bisson, M., Gagne, R., Tessier, A. (1977). Critical evaluation of the copper (II) solubilization method for the determination of the complexation capacity of natural waters. Analyt. Chem. 49: 2358-2363

Carpenter, K. E. (1927). The lethal action of soluble metallic salts on fishes. Brit. J. exp. Biol. 4: 378-390

Duursma, E. K., Sevenhuysen, W. (1966). Note on chelation and solubility of certain metals in sea water at different pH values. Neth. J. Sea Res. 3 (1): 95-106

El Mednaoui, H., Castetbon, A., Astruc, M. (1984). Copper speciation and behaviour at a coastal water-sediment boundary (Bassin d'Arcachon). Environ. Technol. Lett. 5: $525-540$

Fenchel, T. (1975). Factors determining the distribution patterns of mud snails (Hydrobiidae). Oecologia (Berl.) 20: $1-17$

Fenchel, T., Kofoed, L. H., Lappalainen, A. (1975). Particle size-selection of two deposit feeders: the amphipod Corophium volutator and the prosobranch Hydrobia uvae. Mar. Biol. 30: 119-128

Fish, W., Morel, F. M. M. (1983). Characterization of organic copper-complexing agents released by Daphnia magna. Can. J. Fish. Aquat. Sci. 40: 1270-1277

Gardner, W. S., Miller, W. H. (1981). Intracellular composition and net release rates of free amino acids in Daphnia magna. Can. J. Fish. Aquat. Sci. 38: 157-162

George, S. G., Coombs, T. L. (1977). The effects of chelating agents on the uptake and accumulation of cadmium by Mytilus edulis. Mar. Biol. 39: 261-268

Goldman, J. C. (1984). Oceanic nutrient cycles. In: Fasham, M. J. R. (ed.) Flows of energy and material in marine ecosystems. NATO Conference series - Serie IV: Marine sciences. Plenum Press, New York, p. 137-170

Hahne, H. Ch., Kroontje, W. (1973). Significance of $\mathrm{pH}$ and chloride concentration on behavior of heavy metal pollutants: mercury (II), cadmium (II), zinc (II) and lead (II). J. environ. Qual. 2 (4): 444-450

Hart, B. T., Davies, S. H. R. (1981). Copper complexing capacity of waters in the Magela Creek system, northern Australia. Environ. Technol. Lett. 2: 205-214

Hauck, K. W., Dillard, J. W. (1977). Evaluation of micromolar complexometric titrations for the determination of the complexing capacity of natural waters. Analytica chim. Acta 89: $399-438$

Heyrovsky, H., Vavricka, S. (1972). On the pH-dependance of polarographic half-wave potentials. J. electrochem. Chem. Soc. 36: 223-233

Howell, R. (1982). The secretion of mucus by marine nematodes (Enoplus spp.): a possible mechanism influencing the uptake and loss of heavy metal pollutants. Nematologica. Brill, E. J., Leiden 28: 110-114

Jardin, W. F., Pearson, H. W. (1984). A study of the coppercomplexing compounds released by some species of cyanobacteria. Wat. Res. 18 (8): 985-989

Jorgensen, N. O. G. (1980). Uptake of glycine and release of primary amines by the polychaete Nereis virens Sars and the mud snail Hydrobia neglecta Muus. J. exp. Mar. Biol. Ecol. 47: 281-297
Kofoed, L. H. (1975a). The feeding biology of Hydrobia ventrosa Montagu. I. The assimilation of different components of the food. J. exp. mar. Biol. Ecol. 19: 233-241

Kofoed, L. H. (1975b). The feeding biology of Hydrobia ventrosa Montagu. II. Allocation of the components of the carbon-budget and the significance of the secretion of dissolved organic material. J. exp. mar. Biol. Ecol. 19: 243-256

Levinton, J. S. (1979). The effect of density upon depositfeeding populations: movement, feeding and floating of Hydrobia ventrosa Montagu (Gastropoda: Prosobranchia). Oecologia (Berl.) 43: 27-39

Levinton, J. S., Bianchi, T. S. (1981). Nutrition and food limitation of deposit-feeders. The role of microbes in the growth of sand snails (Hydrobiidae). J. mar. Res. 39 (3): $531-545$

Lopez, G. R., Levinton, J. S. (1978). The availability of microorganisms attached to sediment particles as food for Hydrobia ventrosa Montagu (Gastropoda: Prosobranchia). Oecologia (Berl.) 32: 263-275

McCrady, J. K., Chapair, G. A. (1978). Determination of copper complexing capacity of natural river water, well water and artificially reconstituted water. Wat. Res. 13: 143-150

McKnight, D. M., Morel, F. M. M. (1979). Release of weak and strong copper-complexing agents by algae. Limnol. Oceanogr. 24: 823-837

McKnight, D. M., Morel, F. M. M. (1980). Copper complexation by siderophores from filamentous blue-green algae. Limnol. Oceanogr. 25: 62-71

McKone, C. E., Young, R. G., Bache, C. A., Lisk, D. J. (1971). Rapid uptake of mercuric ion by goldfish. Environ. Sci. Technol 5: 1138-1139

Mantoura, R. F. C., Dickson, A., Riley, J. P. (1978). The complexation of metals with humic materials in natural waters. Estuar. coast. mar. Sci. 6: 387-406

Marchandise, P., Olie, J. L., Robbe, D., Legret, M. (1981). Rapport de comparaison interlaboratoires de diverses méthodes de minéralisation. Ministère de l'Environnement et du Cadre de Vie, Paris

Morel, F. M. M., Hudson, R. J. M. (1984). The geobiological cycle of trace elements in aquatic systems: Redfield revisited. In: Stumm, W. (ed.) Chemical processes in lakes. Wiley, New York, p. 62-74

Neiland, J. B. (1981). Microbial iron compounds. Ann. Rev. Biochem. 50: 715-731

Newell, R. C. (1965). The role of detritus in the nutrition of two marine deposit-feeders, the prosobranch Hydrobia ulvae and the bivalve Macoma balthica. Proc. zool. Soc. Lond. 144: 25-42

Newell, R. C. (1970). Biology of intertidal animals. Logos Press Ltd., London

Noël-Lambot, F., Verthe, C., Bouquegneau, J. M. (1981). Effets de quelques complexants organiques sur l'accumulation du cadmium par un mollusque prosobranche et un crustacé mysidacé. Bull. Soc. R. Sci. Liège 50 (11-12): 501-503

Odier, M., Plichon, V (1971). Le cuivre en solution dans l'eau de mer: forme chimique et dosage. Analytica chim. Acta 55: 209-220

Pandian, T. J. (1975). Mechanisms of heterotrophy. In: Kinne, O. (ed.) Marine ecology, Vol. II, Physiological mechanisms, Part 1. John Wiley, London, p. 61-249

Pesch, P. E., Morgan, D. (1978). Influence of the sediment in copper toxicity tests with the polychaete Neanthes arenaceodentata. Wat. Res. 12: 747-751

Rashid, M. A. (1974). Adsorption of metals on sedimentary and peat humic acids. Chem. Geol. 13: 115-123 
Rullier, F. (1959). Etude bionomique de l'Aber de Roscoff. Travaux de la Station Biologique de Roscoff, Tome X

Shuman, M. S. (1982). Exchange of comments on evaluation of the copper Anodic Stripping Voltammetry complexometric titration for complexing capacities and conditional stability constants. Analyt. Chem. 54: 998-1000

Stephens, G. C., Volk, M. J., Wright, S. H., Backlund, P. S. (1978). Transepidermal accumulation of naturally occurring amino acids in the sand dollar Dendraster excentricus. Biol. Bull. mar. biol. Lab., Woods Hole, 154: 335-347

Sueur, S., van Den Berg, M. G., Riley, P. (1982). Measurement of the metal complexing ability of exudates of marine macroalgae. Limnol. Oceanogr. 27 (3): 536-543

Truitt, R. E. (1981). Determination of complexing capacity of fulvic acid for copper (II) and cadmium (II) by Dialysis Titration. Analyt. Chem. 53: 337-342

Tuschall, J. R., Jr., Brezonik, P. L. (1981). Evaluation of the copper Anodic Stripping Voltammetry complexometric titration for complexing capacities and conditional stability constants. Analyt. Chem. 53: 1986-1989

Varanasi, U., Robisch, P. A., Malins, D. C. (1975). Structural alterations in fish epidermal mucus produced by waterborne lead and mercury. Nature, Lond. 258: 431-432

Welte, B., Bles, M., Montiel, A. (1983). A study of different methods of speciation of heavy metals in sediments. Environ. Technol. Lett. 4: 79-88

Westall, J. C., Morel, F. M. M., Hume, D. N. (1979). Chloride interference in cupric ion selective electrode measurement. Analyt. Chem. 51 (11): 1792-1798

Wright, S. H., Stephens, G. C. (1978). Removal of amino acids during a single passage of water across the gill of marine mussels. J. exp. Zool. 205: 337-352

Zirino, A., Yamamoto, S. (1972). A pH-dependent model for the chemical speciation of copper, zinc, cadmium and lead in sea water, Limnol. Oceanogr. 11 (5): 661-671

This article was submitted to the editor; it was accepted for printing on August 16, 1986 